\title{
Effects of photobiomodulation in the treatment of pressure sores
}

\author{
Efeitos da fotobiomodulação no tratamento de lesões por pressão \\ Efectos de la fotobiomodulación en el tratamiento de las lesiones por presión
}

Received: 03/15/2021 | Reviewed: 03/21/2021 | Accept: 03/25/2021 | Published: 04/03/2021

ORCID: https://orcid.org/0000-0003-1920-5367 Christus Faculdade do Piauí, Brazil

E-mail: marianasouza_s@ @otmail.com

Sabrina Beatriz Mendes Nery

ORCID: https://orcid.org/0000-0002-8254-0152 Christus Faculdade do Piauí, Brazil

E-mail: sabrinaanery2019@gmail.com

Daniel Lopes Araújo

ORCID: https://orcid.org/0000-0002-1625-0368

Universidade Federal de Pernambuco, Brazil

E-mail: araujodanielopes@gmail.com

Anne Heracléia de Brito e Silva

ORCID: https://orcid.org/0000-0002-3414-8308

Christus Faculdade do Piauí, Brazil

E-mail: anneheracleiabs@hotmail.com

José Eufrazino Júnior

ORCID: https://orcid.org/0000-0002-4093-7952

Christus Faculdade do Piauí, Brazil

E-mail: eufrazinojunior@gmail.com

Ana Paula Melo Oliveira

ORCID: https://orcid.org/0000-0003-3328-9624

Christus Faculdade do Piauí, Brazil

E-mail: apmelo98@gmail.com

Ana Roza Carvalho Silva

ORCID: https://orcid.org/0000-0002-8804-2832

Christus Faculdade do Piauí, Brazil

E-mail: anaroza.carvalho@gmail.com

Luciana Aparecida da Silva

ORCID: https://orcid.org/0000-0002-6653-3817

Christus Faculdade do Piauí, Brazil

E-mail: nurselucianasilva@hotmail.com

Getulivan Alcantara de Melo

ORCID: https://orcid.org/0000-0001-9310-2046 Christus Faculdade do Piauí, Brazil

E-mail: getuilican01@gmail.com

Karina de Souza Lobo Borralho

ORCID: https://orcid.org/0000-0003-0909-0367

Faculdade Pitágoras, Brazil

E-mail: karinaloboborralho@outlook.com

Guilherme Antônio Lopes de Oliveira

ORCID: https://orcid.org/0000-0003-3820-0502 Christus Faculdade do Piauí, Brazil

E-mail: guilhermelopes@live.com

George Marcos Dias Bezerra

ORCID: https://orcid.org/0000-0002-4720-9077 Christus Faculdade do Piauí, Brazil

E-mail: marcos.george.gm@gmail.com

Gabrielly Silva Ramos

ORCID: https://orcid.org/0000-0003-0767-1352 Christus Faculdade do Piauí, Brazil

E-mail: gabiramos2304@gmail.com

Carliane Maria de Araújo Souza

ORCID: https://orcid.org/0000-0002-8196-0008 Christus Faculdade do Piauí, Brazil

E-mail: kku_ka@hotmail.com

Alcione Rodrigues Chaves Junior

ORCID: https://orcid.org/0000-0003-4372-479X

Christus Faculdade do Piauí, Brazil

E-mail: junior17chaves@gmail.com 
Vanessa Cristina Mendes Luz

ORCID: https://orcid.org/0000-0001-7060-5863 Christus Faculdade do Piauí, Brazil

E-mail: mendesvanessa703@gmail.com

Jeovânia Canidé da Costa

ORCID: https://orcid.org/0000-0001-6250-1554

Faculdade Pitágoras, Brazil

E-mail: jeovania12@gmail.com

\begin{abstract}
Pressure ulcers (PUs) are a cause of concern in health care institutions due to the negative effects they cause to patients, such as pain, infection, and delayed functional recovery. From this perspective, in order to accelerate wound healing, more current treatments are being explored. Among these treatments, the photobiomodulation (FBM) offered by low power laser therapy (LBP) stands out. Given the above, this paper aims to analyze the effects of photobiomodulation in the treatment of PUs. This is an integrative literature review, with searches carried out in MEDLINE, SCIELO and BDENF databases, in which complete papers were included, in Portuguese and English, available electronically and free of charge, published from 2015 to 2021 and that addressed the proposed theme. Studies that did not address the subject of interest or did not answer the guiding question were excluded, as well as duplicate publications in more than one database. The study was composed of the analysis of 8 publications. The findings showed that this therapy contributes to pain reduction, increases local vascularization and accelerates the process of tissue healing, favoring a positive evolution during the treatment of injuries. Thus, it is emphasized that the use of MBP is of paramount importance for the treatment of PUs, because when used in the correct manner, with a qualified professional, it presents positive results in the healing period of the lesion, regardless of the type of associated dressing.
\end{abstract}

Keywords: Pressure ulcer; Laser therapy; Wound healing; Treatment outcome.

\title{
Resumo
}

As lesões por pressão (LPs) geram motivo de preocupação nas instituições de saúde devido aos efeitos negativos que causam nos pacientes, como dor, infecções e demora da recuperação funcional. Sob esse viés, com o objetivo de acelerar a cicatrização das feridas, tratamentos mais atuais estão sendo explorados. Dentre esses tratamentos, destacase a fotobiomodulação (FBM) oferecida pela terapia com laser de baixa potência (LBP). Diante do exposto, esse trabalho tem como objetivo analisar os efeitos da fotobiomodulação no tratamento de lesões por pressão. Trata-se de uma revisão integrativa da literatura, com as pesquisas realizadas nos bancos de dados da MEDLINE, SCIELO e BDENF, em que foram incluídos trabalhos completos, nos idiomas português e inglês, disponíveis eletronicamente e de forma gratuita, publicados no período de 2015 a 2021 e que abordavam a temática proposta. Excluiu-se trabalhos que não abordavam o assunto de interesse ou não respondessem à questão norteadora, além de publicações duplicadas em mais de uma base de dados. O estudo foi composto pela análise de 8 publicações. Os achados mostraram que esta terapêutica contribui para a redução da dor, aumenta a vascularização local e acelera o processo de cicatrização tecidual, favorecendo uma evolução positiva no decorrer do tratamento de lesões. Dessa forma, salienta-se que o uso da FBM é de suma importância para o tratamento de LPs, pois a mesma, quando utilizada da maneira correta, com um profissional habilitado, apresenta resultados positivos no período da cicatrização da lesão, independentemente do tipo de curativo associado.

Palavras-chave: Úlceras por pressão; Terapia a laser; Cicatrização de feridas; Resultado do tratamento.

\section{Resumen}

Las lesiones por presión (LPs) son motivo de preocupación en las instituciones de salud debido a los efectos negativos que causan en los pacientes, como el dolor, las infecciones y la demora en la recuperación funcional. En este sentido, con el objetivo de acelerar la cicatrización de las heridas, se están explorando más tratamientos actuales. Entre estos tratamientos, destaca la fotobiomodulación (FBM) que ofrece la terapia láser de baja potencia (LPB). A partir de la exposición, este trabajo tiene como objetivo analizar los efectos de la fotobiomodulación en el tratamiento de las lesiones por presión. Se trata de una revisión bibliográfica integradora, con búsquedas realizadas en las bases de datos MEDLINE, SCIELO y BDENF, en la que se incluyeron trabajos completos, en portugués e inglés, disponibles en formato electrónico y gratuito, publicados entre 2015 y 2021 y que abordaran el tema propuesto. Se excluyeron los estudios que no abordaban el tema de interés o no respondían a la pregunta guía, así como las publicaciones duplicadas en más de una base de datos. El estudio se compone del análisis de 8 publicaciones. Los resultados mostraron que esta terapia contribuye a la reducción del dolor, aumenta la vascularización local y acelera el proceso de curación de los tejidos, favoreciendo una evolución positiva durante el tratamiento de las lesiones. Así, se destaca que el uso de la FBM es de suma importancia para el tratamiento de las LPs, ya que, cuando se utiliza de forma correcta, con un profesional cualificado, presenta resultados positivos en el periodo de curación de la lesión, independientemente del tipo de apósito asociado.

Palabras clave: Úlceras por presión; Terapia con láser; Curación de heridas; Resultado del tratamiento. 


\section{Introduction}

In 2016, the National Pressure Ulcer Advisory Panel (NPUAP) changed the terminology from pressure ulcer (PU) to pressure ulcer injury (PLI). Thus, throughout the text both terms are applied in order to respect the title of the selected papers. Pressure ulcers (PUs) are defined as an injury to the skin and/or underlying soft tissue that is usually over a bony prominence or associated with medical devices or other artifacts (National pressure ulcer advisory and pan pacific pressure injury alliance, 2015).

These injuries generate concern in health care units because of the negative effects they cause in patients, such as pain, infections and delay in functional recovery. In addition, they cause increased morbidity and mortality, prolonged hospitalizations and, consequently, higher costs for institutions (Galetto et al., 2019).

Macedo et al., (2021) emphasize that this type of injury has a multifactorial cause, and may be related to intrinsic and/or extrinsic factors. Intrinsic factors include age, malnutrition, changes in body mass, obesity, vasomotor insufficiency, peripheral vasoconstriction, existence of chronic diseases, and urinary and fecal incontinence; and extrinsic factors include high temperature, increased humidity, friction, and shear.

As for the LPs classification, they may vary from stages 1 to 4, and may still be considered as unclassifiable pressure ulcers and deep tissue pressure ulcers. Such categorization will depend on the damage and tissues affected, and may compromise skin, muscles, and even bones. It is emphasized that depending on the depth and degree of the LP, several problems may arise, such as: septicemia, osteomyelitis, social isolation and reduced quality of life of the patient (Galetto et al., 2019; Loudet et al., 2017; Nogueira; Caliri \& Santos, 2002).

Therefore, it is important that during the evaluation of LPs, pain, pulse, exudate characteristics, size and depth of the wound, as well as signs indicating infection are taken into consideration. Therefore, these factors are relevant for an appropriate treatment approach, in which the wound healing process is considered an ongoing and, in some cases, prolonged treatment. It should be noted that the healing process, in most cases, is complex, with the appearance of cellular and vascular modifications, production and deposition of collagen, synthesis of elastin, cell proliferation, revascularization, until the reduction of the wound (Lucio \& Paula, 2020).

One of the most implemented treatments is dressing with different coverings, however, the advantage of healing in the medium and long term will depend on the size and depth of the lesion, as well as the clinical condition of the patient. From this point of view, in order to accelerate wound healing, more current treatments are being explored. Among these treatments, photobiomodulation (FBM) offered by low-power laser therapy (LBP) stands out (Macedo et al., 2021).

Photobiomodulation with LBP has been employed in treatments of traumatic ulcers and chronic wounds with positive results. Due to its photochemical, photophysical and otobiological effects, the behavior of cells can be changed and, consequently, contributing to tissue repair, reduction of pain and edema, as well as anti-inflammatory effects, formation of new blood vessels, immune response and increase of fibroblasts (Macedo et al., 2021; Ribeiro \& Marangoni, 2020).

Given the above, this study aims to analyze the effects of photobiomodulation in the treatment of PUs.

\section{Methodology}

This is an integrative review of literature, qualitative in nature, developed from qualitative data from studies through a systematic search on the effects of photobiomodulation in the treatment of PUs. The review followed the steps described by Mendes et al., (2008): 1) Choice of the theme and elaboration of the guiding question; 2) Definition of the inclusion and exclusion criteria; 3) Characterization of the information to be obtained from the selected articles; 4) Analysis of the chosen articles; 5) Interpretation of the collected results; 6) Presentation of the review and summary of knowledge. For Pereira et al., 
(2018), qualitative methods are essential for the researcher to know how to interpret with their opinions regarding the studied phenomenon.

At first, the theme established was the effects of photobiomodulation in the treatment of pressure injuries. Subsequently, the guiding question was elaborated: What are the effects of photobiomodulation in the treatment of pressure sores? Next, data collection was carried out in the Medical Literature Analysis and Retrieval System Online (MEDLINE), Scientific Electronic Library Online (SCIELO) and Nursing Database (BDENF) databases.

The terms used for the search were selected using the Descriptors in Health Sciences (DECS): "pressure ulcers" and "laser therapy" and "wound healing" and "treatment outcome", in order to carry out an integrated search, the connective "and" was used, bringing together the descriptors.

In addition, the PICo strategy was used, where the Population (P) was defined: individuals with PUs; Intervention (I): use of photobiomodulation; Comparison $(\mathrm{C})$ : treatment of PUs by photobiomodulation; Outcomes (O): to reduce the healing time of the lesions. This is a strategy used to elaborate the guiding question and to search for scientific evidence in the literature (Santos et al., 2007).

Regarding the inclusion criteria, we included complete papers, in Portuguese and English, available electronically and free of charge, published between 2015 and 2021 and that addressed the proposed theme. Studies that did not address the subject of interest or did not answer the guiding question were excluded, as well as duplicate publications in more than one database.

Figure 1. Flowchart of the papers found in the researched databases.
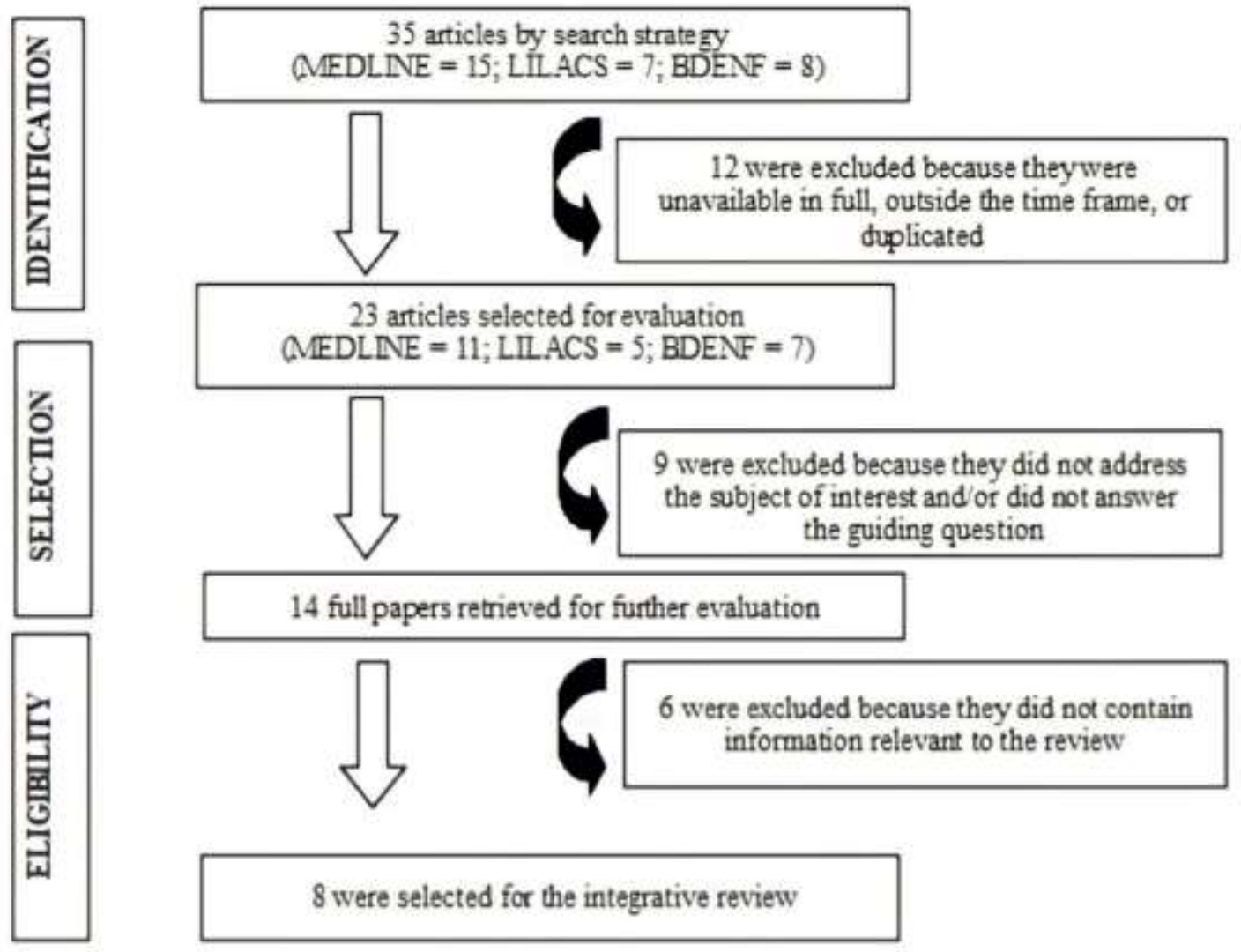

Source: Authors (2021).

After a thorough reading of all complete articles, a data collection tool was applied, containing the following topics: 
title, authors, year of publication, type of study, objectives, and conclusion (Souza, Silva \& Carvalho (2010).

\section{Results and Discussion}

After selecting and reading the articles resulting from the search in the databases through the associated descriptors, a table was produced to display the research covering information such as title, authors, year, type of study, objectives, and conclusion. It is worth mentioning that the articles were selected and analyzed aiming to answer the study's guiding question. A total of eight articles were identified and selected from an extensive review following the methodological steps mentioned above. Subsequently, a discussion was held about the theme addressed in this research, in order to bring evidence on the use of photobiomodulation in the treatment of LPP, and how this method influences the healing process.

Table 1 - Characterization of the articles included in the integrative review according to the title, authors, year, type of study, objectives, and conclusion.

\begin{tabular}{|c|c|c|c|c|}
\hline Title & Authors/Year & $\begin{array}{c}\text { Type of } \\
\text { study }\end{array}$ & Goals & Conclusion \\
\hline $\begin{array}{l}\text { The effectiveness of } \\
\text { laser associated with } \\
\text { different types of } \\
\text { dressings in the healing } \\
\text { of pressure ulcers }\end{array}$ & $\begin{array}{l}\text { De Bortoli, Prato } \\
\text { \& Kroth (2016) }\end{array}$ & $\begin{array}{l}\text { Randomized } \\
\text { Clinical Trial }\end{array}$ & $\begin{array}{l}\text { To verify the } \\
\text { effectiveness of laser } \\
\text { therapy associated with } \\
\text { different types of } \\
\text { dressings in patients of a } \\
\text { university hospital }\end{array}$ & $\begin{array}{l}\text { Regardless of the type of } \\
\text { dressing used, low frequency } \\
\text { laser therapy has shown } \\
\text { positive results for patients. }\end{array}$ \\
\hline $\begin{array}{l}\text { Evaluation of the effect } \\
\text { of photobiomodulation } \\
\text { in traumatic ulcer in } \\
\text { children: clinical case } \\
\text { report }\end{array}$ & $\begin{array}{c}\text { Ribeiro \& } \\
\text { Marangoni (2020) }\end{array}$ & $\begin{array}{l}\text { Clinical case } \\
\text { report }\end{array}$ & $\begin{array}{l}\text { To evaluate the effect of } \\
\text { photobiomodulation on a } \\
\text { traumatic ulcer in a child } \\
\text { patient }\end{array}$ & $\begin{array}{l}\text { Low intensity laser has the } \\
\text { potential to treat traumatic } \\
\text { injuries, reducing pain and } \\
\text { discomfort and accelerating } \\
\text { the healing of traumatic } \\
\text { ulcers. }\end{array}$ \\
\hline $\begin{array}{ll}\text { Effects } & \text { of } \\
\text { photobiomodulation } & \text { in } \\
\text { the treatment } & \text { of } \\
\text { pressure ulcers: } & \text { an } \\
\text { integrative review } & \end{array}$ & $\begin{array}{l}\text { Macedo et al., } \\
\text { (2021) }\end{array}$ & $\begin{array}{l}\text { Integrative } \\
\text { review }\end{array}$ & $\begin{array}{l}\text { To evaluate the effects of } \\
\text { photobiomodulation } \\
\text { with low power laser in } \\
\text { the treatment of pressure } \\
\text { ulcers }\end{array}$ & $\begin{array}{l}\text { Photobiomodulation with low } \\
\text { power laser in the treatment } \\
\text { of pressure ulcers, in } \\
\text { association or not with } \\
\text { adjuvant therapies are } \\
\text { effective in the treatment of } \\
\text { lesions. }\end{array}$ \\
\hline $\begin{array}{l}\text { Effects of laser therapy } \\
\text { in the treatment of PUs: } \\
\text { a systematic review }\end{array}$ & $\begin{array}{c}\text { de Oliveira } \\
\text { Bernardes \& } \\
\text { Jurado (2018) }\end{array}$ & $\begin{array}{l}\text { Systematic } \\
\text { review }\end{array}$ & $\begin{array}{l}\text { To study the efficacy of } \\
\text { laser therapy in the } \\
\text { healing process of PUs }\end{array}$ & $\begin{array}{l}\text { The low power laser shows } \\
\text { itself as a favorable treatment } \\
\text { for wound healing, because it } \\
\text { increases the healing speed, } \\
\text { improves the } \\
\text { microcirculation and reduces } \\
\text { the expenses with } \\
\text { conventional coverings }\end{array}$ \\
\hline $\begin{array}{l}\text { Photobiomodulation in } \\
\text { the healing process of } \\
\text { injuries: a case study }\end{array}$ & $\begin{array}{l}\text { Lucio \& Paula } \\
\text { (2020) }\end{array}$ & Case Study & $\begin{array}{l}\text { To present the case of a } \\
\text { diabetic patient with } \\
\text { varicose ulcer, who } \\
\text { underwent treatment } \\
\text { with laser therapy and } \\
\text { high-tech dressings }\end{array}$ & $\begin{array}{l}\text { The laser therapy treatment } \\
\text { was effective and applied by } \\
\text { a qualified professional was a } \\
\text { safe treatment, bringing } \\
\text { positive results to the patient. }\end{array}$ \\
\hline $\begin{array}{l}\text { Photobiomodulation in } \\
\text { the treatment } \\
\text { pressure of ulcers: } \\
\text { review of the literature }\end{array}$ & $\begin{array}{c}\text { de Oliveira et al., } \\
\text { (2019) }\end{array}$ & $\begin{array}{c}\text { Literature } \\
\text { review }\end{array}$ & $\begin{array}{l}\text { Analyze the effects of } \\
\text { photobiomodulation in } \\
\text { the treatment of pressure } \\
\text { ulcers }\end{array}$ & $\begin{array}{l}\text { Photobiomodulation is shown } \\
\text { to be an effective therapy in } \\
\text { the treatment of pressure } \\
\text { ulcers, being effective in } \\
\text { reducing pain, increasing } \\
\text { local vascularization, and } \\
\text { accelerating the healing } \\
\text { process of the tissue. }\end{array}$ \\
\hline
\end{tabular}




\begin{tabular}{|c|c|c|c|c|}
\hline $\begin{array}{l}\text { Impact of low-level } \\
\text { laser therapy on the } \\
\text { dynamics of pressure } \\
\text { ulcer-induced changes } \\
\text { considering an } \\
\text { infectious agent and } \\
\text { cathelicidin LL-37 } \\
\text { concentration: } \\
\text { preliminary study a }\end{array}$ & $\begin{array}{l}\text { Brauncajs et al., } \\
\text { (2018) }\end{array}$ & $\begin{array}{l}\text { Preliminary } \\
\text { Study }\end{array}$ & $\begin{array}{l}\text { Investigate the impact of } \\
\text { low-level laser therapy } \\
\text { on pressure ulcer } \\
\text { dynamics considering an } \\
\text { infectious agent and } \\
\text { cathelicidin LL-37 } \\
\text { concentration }\end{array}$ & $\begin{array}{l}\text { Low-level laser therapy has } \\
\text { potential benefits in } \\
\text { combating the pathogens that } \\
\text { infect pressure ulcers. }\end{array}$ \\
\hline $\begin{array}{l}\text { Laser therapy in } \\
\text { pressure ulcers: } \\
\text { assessment by Pressure } \\
\text { Ulcer Scale for Healing } \\
\text { and Nursing Outcomes } \\
\text { Classification }\end{array}$ & $\begin{array}{l}\text { Palagi et al., } \\
\quad(2015)\end{array}$ & Case Study & $\begin{array}{l}\text { To describe the healing } \\
\text { process of pressure } \\
\text { ulcers in critically ill } \\
\text { patients treated with } \\
\text { conventional healing } \\
\text { therapy plus low } \\
\text { intensity laser therapy as } \\
\text { assessed by the Pressure } \\
\text { Ulcer Scale for Healing } \\
\text { (PUSH) and the Wound } \\
\text { Healing Score }\end{array}$ & $\begin{array}{l}\text { There was improvement in } \\
\text { the pressure ulcer healing } \\
\text { process treated with adjuvant } \\
\text { Low-Level Laser Therapy } \\
\text { (LLLT) and the use of NOC } \\
\text { enabled a more thorough and } \\
\text { accurate assessment than } \\
\text { PUSH }\end{array}$ \\
\hline
\end{tabular}

Source: Authors (2021).

\subsection{Morpho-physiological evolution of lesions during laser treatment and associations}

The study by Bortoli, Prato and Kroth (2016) was a clinical study, with a sample of six patients with PU. They were

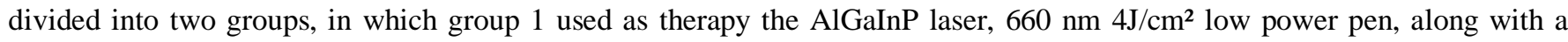
essential fatty acid coverings. And group 2 used the same parameters of the laser, but with papain as coverings. During the analysis of the results, it could be observed that the wounds in which the oil lotion based on Essential Fatty Acid (EFA) with laser therapy was used presented a greater reduction in the area and physical aspects of the skin, such as color, vascularization, and absence of devitalized tissue on the edges; when compared to the wounds treated with papain, an improvement in the healing process was noted, however, a regression in the general condition of the skin, with alterations in color and the presence of devitalized tissue on the edges of the wounds.

Palagi et al., (2015), conducted a case study, in which the patient presented LPP, and after 15 days of treatment with Low Intensity Laser (LLLT), it was observed that the dimensions of the lesion reduced from $7 \mathrm{~cm}$ to $1.5 \mathrm{~cm}$ in length and from $6 \mathrm{~cm}$ to $1.1 \mathrm{~cm}$ in width, in addition to the reduction of secretion and odor, and significant increase in epithelial and granulation tissue. Concluding, therefore, that the intervention with LLLT accelerated tissue proliferation, besides increasing local vascularization, forming granulation tissue by promoting rapid healing of the lesion. It is noteworthy that the coverings used was in accordance with the protocol of the institution, including the use of heated $0.9 \%$ saline solution, used for hygiene of the lesion and specific coverings used according to the evolution of the lesion, such as zinc oxide, medium chain triglycerides, hydrogel and silver alginate, along with LBP.

In the study by Lucio and Paula (2020) they report the treatment of a lesion in a 67-year-old patient with diabetes mellitus and hypertension. The treatment was the use of LBP together with silver hydrofilm and hydrogel with calcium and sodium alginate. After 55 days of treatment, there was a gradual improvement of the devitalized tissue, and thus total retraction of the lesion, occurring the healing process. Corroborating these findings, de Oliveira Bernardes and Jurado (2018) address that the healing period in elderly individuals is possibly reduced, due to the aging process. Besides being more vulnerable to the emergence of ulcers for other reasons, as in the case of diabetic wounds.

Ribeiro and Marangoni (2020), concluded through a case study carried out in an 8-year-old child with traumatic ulcer, that photobiomodulation is an effective method in the treatment of this ulcer, because after starting treatment by irradiation 
with LLLT for analgesia and aid in the healing of the lesion, it was observed an immediate positive result after irradiation, in which the patient reported an improvement in pain. After 9 days, there was total repair of the lesion, and a score of 3 in relation to pain, showing an improvement with regard to the evolution of the traumatic ulcer.

Corroborating with the studies cited, de Oliveira et al., (2019), it was possible to observe several methodological strategies regarding the protocol for treatment with photobiomodulation, however, in all the manuscripts analyzed, it was noted an outcome presenting expressive improvement in the painful picture and in the healing process of the lesions regardless of the therapy used. Complementarily, despite the differences in treatment protocols and strategies, the findings indicate that photobiomodulation contributes to pain reduction, besides increasing local vascularization and accelerating tissue healing, contributing to a positive evolution during the treatment of PUs.

\subsection{Multidimensional effectiveness of photobiomodulation in the healing process}

In the research conducted by Macedo et al, (2021), concluded that photobiomodulation with LBP in the treatment of PU, associated or not with adjuvant therapies, such as essential fatty acid based coverings and microcurrent are effective in treating lesions. The efficacy was described in all groups evaluated with LBP with a wavelength in the $660 \mathrm{~nm}$ range (red) and a dose of $4 \mathrm{~J} / \mathrm{cm}^{2}$. This shows that the various approaches expose the heterogeneous nature of the studies, and that there is no effective standardization of the type of laser used, as well as the exposure time and periodicity.

The study by Palagi et al. (2015), brings as a possibility the use of LBP in protocols for the treatment of PU, because through this case study, associated with the literature, it could be observed that this method accelerated tissue proliferation, in addition to increasing local vascularization, favoring a rapid healing of the lesion. Through this study, we concluded on the effectiveness of the use of LBP in the process of pressure ulcer healing, and this therapy should be highlighted as an effective alternative in the treatment of PUs in a critically ill patient.

According to Ribeiro and Marangoni (2020), the present study points to photobiomodulation as an analgesic and reparative alternative for the treatment of traumatic ulcers. In agreement with this study, Lucio and Paula (2020), point out that the use of laser therapy is of paramount importance during the wound healing process, because it is a method that through its anti-inflammatory, analgesic and tissue repair action, provides improvement in the patient's well-being and possibly causes a positive impact on their quality of life. In this study, the treatment using laser therapy proved to be an effective resource, and that when performed by a trained professional, it becomes a safe treatment, showing a significant improvement in the patient's condition.

In this same sense, the study by de Oliveira Bernardes and Jurado (2018) shows that the healthcare professional must have knowledge about the theoretical basis of laser therapy, in addition to the purpose of the laser, because this way the treatment will become effective and obtain the maximum therapeutic benefit. It is noteworthy that according to this study, the use of LBP is capable of reducing the number of bacterial colonies present in pressure lesions.

These findings corroborate with Brauncajs et al., (2018) in which they bring in their study that LBP therapy has potential benefits in combating pathogens that infect pressure ulcers. In agreement with these findings, de Oliveira et al., (2019) point out that photobiomodulation is taken as an effective therapy with regard to the treatment of pressure ulcers. Thus, suggesting that it should be considered as a treatment method for these disorders, reducing the length of hospital stays.

\section{Conclusion}

Therefore, the use of photobiomodulation with LBP is of paramount importance for the treatment of PUs, because when used correctly, by a qualified professional, it presents as a positive result in the healing period of the lesion, regardless of the type of associated dressing. Furthermore, it is important to highlight the need for this therapy to be implemented in the 
treatment of this type of disease, as it was observed that it contributes significantly to improving the quality of life of patients, besides possibly reducing the length of hospital stays.

Furthermore, it is necessary to develop irradiation protocols that can elucidate the correct dose for each case, increasing the credibility of this type of therapy. More studies focused on this theme are essential, because through these findings, it is noted that photobiomodulation has been a promising method in the treatment of wounds, considering that it increases the speed of healing, promotes analgesia, improves circulation, and reduces the cost of conventional dressings. Thus, it is recommended that clinical studies be developed in different scenarios, seeking to bring more evidence regarding the treatment using LBP in the healing process of injuries, which would result in a standardization of the indication of this method.

\section{References}

Brauncajs, M. Ksiąszczyk, k. Lewandowska-Polak, A. Gorzela, K. Grzegorczyk, J. (2018). Impacto da terapia a laser de baixa potência na dinâmica das alterações induzidas por úlcera de pressão considerando um agente infeccioso e a concentração de catelicidina LL-37: um estudo preliminar. Advances in Dermatology and Allergology/Postępy Dermatologii i Alergologii, 35(6), 582, https://doi.org/10.5114/ada.2018.77609.

De Bortoli, I., Prato, A. L., \& Kroth, A. (2016). A efetividade do laser associado a diferentes tipos de curativos na cicatrização de úlceras de pressão. Evidência, 16(1). http://dx.doi.org/10.18593/eba.v16i1.9774.

de Oliveira, K. F., da Silva, M. L., Morais, R. M., Rodrigues, T. S., Silveira, G. W. S., \& Paiva-Oliveira, E. L. (2019). Fotobiomodulação no tratamento de úlceras por pressão: revisão da literatura. Revista científica da faminas, 14(1). http://periodicos.faminas.edu.br/index.php/rcfaminas/article/view/395.

de Oliveira Bernardes, L., \& Jurado, S. R. (2018). Efeitos da laserterapia no tratamento de lesões por pressão: uma revisão sistemática. Revista Cuidarte, 9(3), 2423-34. http://dx.doi.org/10.15649/cuidarte.v9i3.574.

Galetto, S. G. D. S., Nascimento, E. R. P. D., Hermida, P. M. V., \& Malfussi, L. B. H. D. (2019). Lesões por Pressão Relacionadas a Dispositivos Médicos: revisão integrativa da literatura. Revista Brasileira de Enfermagem, 72(2), 505-512. https://dx.doi.org/10.1590/0034-7167-2018-0530.

Loudet, C. I., Marchena, M. C., Maradeo, M. R., Fernández, S. L., Romero, M. V., Valenzuela, G. E., \& Estenssoro, E. (2017). Diminuição das úlceras por pressão em pacientes com ventilação mecânica aguda prolongada: um estudo quasi-experimental. Revista Brasileira de Terapia Intensiva, 29(1), 39-46. https://dx.doi.org/10.5935/0103-507x.20170007.

Lucio, F. D., \& Paula, C. F. B. (2020). Fotobiomodulação no processo cicatricial de lesões-estudo de caso. CuidArte, Enferm, 111-114. http://www.webfipa.net/facfipa/ner/sumarios/cuidarte/2020v1/p.111-114.pdf.

Macedo, S. P. R., de Almeida Mota, M. S., Fagundes, C. F., de Souza, M. R., \& Navarro, R. S. (2021). Efeitos da fotobiomodulação no tratamento de úlceras por pressão: Revisão integrativa. Research, Society and Development, 10(2), e32810212597-e32810212597. http://dx.doi.org/10.33448/rsd-v10i2.12597.

Mendes, K. D. S., Silveira, R. C. D. C. P., \& Galvão, C. M. (2008). Revisão integrativa: método de pesquisa para a incorporação de evidências na saúde e na enfermagem. Texto \& contexto-enfermagem, 17(4), 758-764. https://doi.org/10.1590/S0104-07072008000400018.

National Pressure Ulcer Advisory and Pan Pacific Pressure Injury Alliance. (2015). Prevention and Treatment of Pressure Ulcers: Quick Reference Guide. In Clinical Practice Guideline.

Nogueira, P. C., Caliri, M. H. L., \& Santos, C. B. (2002). Fatores de risco e medidas preventivas para úlcera de pressão no lesado medular. Experiência da equipe de enfermagem do HCFMRP-USP. Medicina (Ribeirao Preto Online), 35(1), 14-23. https://doi.org/10.11606/issn.2176-7262.v35i1p14-23

Palagi, S., Severo, I. M., Menegon, D. B., \& Lucena, A. D. F. (2015). Laserterapia em úlcera por pressão: avaliação pelas Pressure Ulcer Scale for Healing e Nursing Outcomes Classification. Revista da Escola de Enfermagem da USP, 49(5), 826-833. https://doi.org/10.1590/S0080-623420150000500017.

Pereira, A. S., Shitsuka, D. M., Parreira, F. J., \& Shitsuka, R. (2018). Metodologia da pesquisa científica. UFSM

Ribeiro, T. E., \& Marangoni, A. F. (2020). 13. Avaliação do efeito da fotobiomodulação em úlcera traumática em crianças: relato de caso clínico. Revista Científica UMC, 5(1). http://seer.umc.br/index.php/revistaumc/article/view/701.

Santos, C. M. D. C., Pimenta, C. A. D. M., \& Nobre, M. R. C. (2007). A estratégia PICO para a construção da pergunta de pesqu isa e busca de evidências. Revista Latino-Americana de Enfermagem, 15(3), 508-511. https://dx.doi.org/10.1590/S0104-11692007000300023

Souza, M. T. D., Silva, M. D. D., \& Carvalho, R. D. (2010). Revisão integrativa: o que é e como fazer. Einstein (São Paulo), 8(1), $102-106$. 